\title{
Relationship between Organizational Justice Perceptions and Organizational Commitment Levels of School of Physical Education and Sports Academicians*
}

\author{
Abdil Ari ${ }^{1}$, Hakan Salim Çağlayan ${ }^{1}$ \\ ${ }^{1}$ Selcuk University, Faculty of Sport Sciences, Department of Sports Management, Konya, Turkey \\ Correspondence: Hakan Salim Çağlayan, Selcuk University, Faculty of Sport Sciences, Department of Sports \\ Management, Konya, Turkey.
}

Received: February 7, 2017

Accepted: March 2, 2017

Online Published: March 23, 2017

doi:10.11114/jets.v5i4.2201

URL:https://doi.org/10.11114/jets.v5i4.2201

\begin{abstract}
This study was conducted to determine organizational justice perceptions and organizational commitment levels of the school of physical education and sports academicians and to establish whether there is a relation between their organizational justice perceptions and organizational commitment levels or not.

In the study, a method for the descriptive survey and relational survey aiming at the revelation of the current state was used. The sample group of the study was constituted by aggregately 524 academicians [Professors $(\mathrm{n}=5)$, Associate Professors $_{(\mathrm{n}=62)}$, Assistant Associate Professors ${ }_{(\mathrm{n}=172)}$, Lecturers $\mathrm{n}_{(\mathrm{n}=104)}$, Instructors $\mathrm{n}_{(\mathrm{n}=82)}$, Research Assistants $\left._{(\mathrm{n}=99)}\right]$. As a data collection tool, the "Organizational Justice Scale" developed by Niehoff and Moorman (1993) and adapted in Turkish by Yıldırım (2002), the "Organizational Commitment Scale" developed by Meyer et al (1993), and "Personal Information Form" developed by the researcher were utilized in the study.

In the analysis of the data, Spearman Brown Rank Correlation (r) coefficient technique was used to reveal the difference between the organizational justice perceptions and the organizational commitment levels of the academicians. In the study, $\alpha=0.05$ was chosen as a level of significance.

In consequence of the study, the highest perceptions of the school of physical education and sports academicians regarding justice was determined to be in the allocative justice dimension, which was followed by the interactional justice and transactional justice dimensions, and that the allocative, interactional, and transactional justice perceptions of the academicians regarding their institutions was at "moderate" levels in general, that is to say, they were not content with the decisions taken at the latter justice dimensions.

It was determined that the highest perception of the school of physical education and sports academicians regarding commitment were in the emotional commitment dimension, that it was followed by the attendance commitment and normative commitment dimensions, and that, in general, the emotional commitments of the academicians regarding their institutions was high and their attendance and normative commitments were at "moderate" level.
\end{abstract}

It was determined that moderate and low level positive relationships between the organizational justice dimensions and organizational commitment dimensions of the school of physical education and sports academicians are present.

Keywords: academician; school of physical education and sports; organizational justice; organizational commitment

\section{Introduction}

The study is one of the most central areas of human life, as a social activity that ensures the continuity of life, whose past dates back to the existence of humanity. Working life constitutes the centerline of the life of humans and humans are also at the focal point of working life. In the orderly and accurate functioning of a human-focused working life, the value attached to the human resource is substantially important (Eğilmezkol, 2011). As long as humans remain insufficient in fulfilling their endless needs by utilizing the limited means at hand, they are obliged to interact with other

\footnotetext{
*This study was presented as an Oral Statement at the $2^{\text {nd }}$ International Conference on The Changing World and Social Research (ICWSR'2016)' Congress held on 14-16 October 2016 in Barcelona/Spain.
} 
people and supply the resources they are short of by means of exchanging with them. Thanks to it, the humans coming together around shared objectives create both material and emotional connections among them by constituting organizations (Bağc1, 2013).

An organization must make an effective use of the human factor, which forms one of its most important resources, in order to reach their objectives, adapt to the rapid changes and developments brought along by the age, and ensure their continuity in a competitive world (Yazıcıoğlu and Topaloğlu, 2009).

Ensuring organizational justice within an organization for the efficient and effective functioning of human resources and, accordingly, increasing organizational commitment are extremely important issues (İmamoğlu, 2011). It appears that the issue of "organizational commitment and organizational justice" is a significant factor in the elimination of the discrepancies posed by the ratio of labor turnover. The area in question is highly important for the employees and the quality, efficiency, and effectiveness of the goods and services produced by institutions, regardless of whether they are public or private sectors (Belli and Ekici, 2012). In this frame, organizational justice certainly points out a negative or positive perception that an individual can obtain from his/her relation with the organization. In addition, it will be easy to assert that bilateral understandings, approaches, and implementations toward the employees against the fact that an organization is a bunch of relations with equal distance in all aspects of all the employees might cause the intention of leaving the organization. At this point, the importance of the concept of organizational justice and commitment comes to the foreground once again because commitment highlights the continuation of an invested human resource in any manner to be active within an organization or, in more specific terms, its continuation of its qualified contribution. In addition, in view of its own framework, organizational commitment requires a transfer to an administrative area of implementation (K1ray, 2011). Presently, most people spend a significant portion of their days at their workplaces. It is possible to mention many work-specific factors that inflict negative or positive impacts on an individual physically or psychologically. Besides, the concepts of organizational justice and organizational commitment that take a large part in the industry and organizational psychology studies have a significant place among those factors (Arslantürk and Şahan, 2012).

Organizational commitment that has positive results for organizations can be increased by means of creating a sense of organizational justice in the employees. Hence, organizational justice has the potential of affecting such positive behaviors by way of organizational commitment (İmamoğlu, 2011). It is clear that the employees feeling high level of commitment toward their organization will provide more beneficial contributions than those employees feeling lower level of commitment in the issues like attaining the organizational objectives and, as a result, ensuring organizational efficiency, and they will play key role in ensuring their organization's competitive advantage against the competitors. Various studies conducted have demonstrated that the perception of organizational justice is a significant determinant of the organizational commitments of employees (Bağc1, 2013).

It appears within the literature that studies have been performed regarding the determination of the organizational justice perceptions of academicians (Kıray, 2011), their organizational commitment levels (Boylu et al., 2007; Kurtbaş, 2011; Özgan et al., 2012; Bozkurt and Yurt, 2013; Ay et al., 2015), and the relation between their organizational justice perceptions and organizational commitment perceptions (K1ray, 2011). However, no study regarding whether a relation between the organizational justice perceptions and organizational commitment levels of school of physical education and sports academicians is present or not has been encountered within the literature.

In the light of the foregoing information, the study has been conducted with the school of physical education and sports academicians, who constitute the sports-based human resource of the academic world that has a difficult environment, to determine their perception toward organizational justice and their organizational commitment levels and whether there is relation between their organizational justice perceptions and organizational commitment levels. It is considered that the study will, in this form of it, contribute to the sports-related units of both public and private universities to be a step ahead in the increasingly competitive environment; that it will provide the executives of such units with an idea for a good organizational management, implementation of the modern management principles and functions, and development of commitment, satisfaction, and performance levels by exhibiting a fair approach among the employees; and that it will guide them in terms of the steps that must be taken.

\section{Method}

\subsection{The Model of the Study}

In the study, a method regarding relational screening and descriptive screening (survey) aiming to clarify the current status has been used.

\subsection{Population and Sample}

The population of the study is constituted by the academicians (lecturers, teaching assistants, instructors, experts, and 
researchers) working at 54 Schools of Physical Education and Sports, 6 Sportive Sciences Faculties, 5 Teacher Training Schools of Physical Education and Sports acting under Teacher Training Faculties, and 2 Schools of Higher Education for Sportive Sciences and Technology, which operate under the universities in Turkey admitting students in accordance with the Table 4 (Higher Education Undergraduate Programs Admitting Students through Central Placement) and Table 5 (Higher Education Undergraduate Programs Admitting Students through Special Talent Exam) in the 2014 Higher Education Programs and Contingents Guidebook (ÖSYS, 2014) of the Student Selection and Placement System (ÖSYS).

Sampling method has not been applied for obtaining reliable data and the study was performed on the generality of the population on the basis of volunteer continuation; the "self-sampling population" (Çilenti, 1984) has been acknowledged as the working environment of the study.

In the study, the questionnaire methods of face-to-face meeting and postal services (Büyüköztürk et al., 2014) have been utilized. The intention was to conduct the questionnaire with all academicians in the study but it was not possible in view of those academicians who were absent at the time of the study and the ones who were unwilling to take part in the questionnaire. It was determined at the end of the process that the academicians working at 43 Schools of Physical Education and Sports $(n=464), 3$ Sportive Sciences Faculties $(n=30), 1$ Sportive Sciences and Technology School of Higher Education $(\mathrm{n}=21)$, and 1 Teacher Training School of Physical Education and Sports acting under Teacher Training Faculties $(n=9)$ had taken part in the data collection process of the study. As the population of the study has been determined according to the Higher Education Programs and Contingents Guidebook (ÖSYS, 2014) of the Student Selection and Placement System (ÖSYS), the Schools of Physical Education and Sports that became faculties subsequent to the publication of the Guidebook have been shown as Schools of Higher Education in the table. This way, the sampling

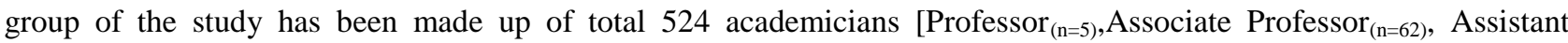
$\operatorname{Professor}_{(\mathrm{n}=172)}, \operatorname{Lecturer}_{(\mathrm{n}=104)}$, Instructor $(\mathrm{n}=82)$, Researcher $\left._{(\mathrm{n}=99)}\right]$. The distributions of the academicians taking part in the study as per their universities and the units where they work are given in details in Table 1: 
Table 1. The Percentage and Frequency Distributions of the Academicians Responding to the Questionnaire.

\begin{tabular}{|c|c|c|}
\hline University and Units & $\mathbf{n}$ & $\%$ \\
\hline Seljuk University PESSHE (Physical Education and Sports School of Higher Education) & 29 & 5,5 \\
\hline Ataturk University PESSHE & 24 & 4,6 \\
\hline Mustafa Kemal University PESSHE & 21 & 4,0 \\
\hline Firat University PESSHE & 20 & 3,8 \\
\hline Erciyes University PESSHE & 19 & 3,6 \\
\hline Dumlupınar University PESSHE & 18 & 3,4 \\
\hline Gaziosmanpaşa University PESSHE & 18 & 3,4 \\
\hline Kırıkkale University PESSHE & 18 & 3,4 \\
\hline Ahi Evran University PESSHE & 17 & 3,2 \\
\hline Düzce University PESSHE & 16 & 3,1 \\
\hline Afyon Kocatepe University PESSHE & 15 & 2,9 \\
\hline İnönü University PESSHE & 15 & 2,9 \\
\hline Kastamonu University PESSHE & 14 & 2,7 \\
\hline Aksaray University PESSHE & 13 & 2,5 \\
\hline Gazi University PESSHE & 12 & 2,3 \\
\hline Marmara University PESSHE & 12 & 2,3 \\
\hline Kahramanmaraş Sütçü İmam University PESSHE & 12 & 2,3 \\
\hline Kafkas University Sarıkamış PESSHE & 12 & 2,3 \\
\hline Niğge University PESSHE & 11 & 2,1 \\
\hline Ağrı İbrahim Çeçen University PESSHE & 11 & 2,1 \\
\hline Batman University PESSHE & 11 & 2,1 \\
\hline Sakarya University PESSHE & 10 & 1,9 \\
\hline Kocaeli University PESSHE & 10 & 1,9 \\
\hline Karabük University Hasan Doğan PESSHE & 10 & 1,9 \\
\hline Yüzüncü Y1l University PESSHE & 10 & 1,9 \\
\hline Karamanoğlu Mehmet Bey University PESSHE & 9 & 1,7 \\
\hline Balıkesir University PESSHE & 9 & 1,7 \\
\hline Harran University PESSHE & 9 & 1,7 \\
\hline Mehmet Akif Ersoy University PESSHE & 8 & 1,5 \\
\hline Ordu University PESSHE & 8 & 1,5 \\
\hline Muğla Sitk1 Koçman University PESSHE & 6 & 1,1 \\
\hline AegeanUniversity PESSHE & 5 & 1,0 \\
\hline Abant İzzet Baysal University PESSHE & 4 & 0,8 \\
\hline Ardahan University PESSHE & 4 & 0,8 \\
\hline Black Sea Technical University PESSHE & 4 & 0,8 \\
\hline Hittite University PESSHE & 4 & 0,8 \\
\hline Cumhuriyet University PESSHE & 3 & 0,6 \\
\hline Çukurova University PESSHE & 3 & 0,6 \\
\hline Çanakkale Onsekiz Mart University PESSHE & 3 & 0,6 \\
\hline Mediterranean University PESSHE & 2 & 0,4 \\
\hline Bülent Ecevit University PESSHE & 2 & 0,4 \\
\hline Trakya University Kırkpınar PESSHE & 2 & 0,4 \\
\hline Bitlis Eren University PESSHE & 1 & 0,2 \\
\hline Anadolu University Sportive Sciences Faculty & 20 & 3,8 \\
\hline Uşak University Sportive Sciences Faculty & 9 & 1,7 \\
\hline Hacettepe University Sportive Sciences Faculty & 1 & 0,2 \\
\hline Pamukkale University Sportive Sciences and TechnologySchool of Higher Education & 21 & 4,0 \\
\hline Erzincan University Teacher Training Faculty Teacher Training School of Physical Education and Sports & 9 & 1,7 \\
\hline Total & 524 & 100.0 \\
\hline
\end{tabular}


As seen in Table 1, the number of the academicians taking part in the questionnaire is 43 Schools of Physical Education and Sports $(n=464), 3$ Sportive Sciences Faculties $(n=30), 1$ Sportive Sciences and Technology School of Higher Education $(\mathrm{n}=21)$, and 1 Teacher Training School of Physical Education and Sports acting under Teacher Training Faculties (n=9), aggregating to 524 individuals.

\subsection{Data Collection Tools}

The data required to attain the objectives specified in the study have been compiled by means of the Personal Information Form developed by the researcher, the "Organizational Justice Scale" developed by Niehoff and Moorman (1993) and adapted to the Turkish language by Yildırım (2002), and "Organizational Commitment Scale" developed by Meyer et al., (1993).

\subsection{Organizational Justice Scale}

The "Organizational Justice Scale" has been developed by Niehoff and Moorman (1993) to determine employees' perception of organizational justice. The work on adaptation of the Scale to the Turkish language, validity, and reliability has been conducted by Yıldırım (2002).

The "Organizational Justice Scale" that has been used in numerous studies within the literature (Atalay, 2007; Erkanl, 2009; Günsal, 2010; Kıray, 2011) consists aggregately of 20 articles. In them, 5 expressions measure (1-5) distributive justice dimension, 6 expressions measure (6-11) procedural justice dimension, and 9 expressions measure (12-20) transactional justice sub-dimensions.

The expressions in question have been graded with the 5-step Likert scale, like "I strongly disagree =1," "I disagree=2," "I don't know=3," "I agree=4," "I strongly agree=5." The high scores in the organizational justice scale express the increase in the perception of justice (Günsal, 2010).

\subsection{Organizational Commitment Scale}

In the study, the 18-article organizational commitment scale developed by Meyer et al., (1993) was utilized to measure the organizational commitment. The expressions within the scale are in the form of 5-step Likert. There are five grades of opinions opposite each expression, like "I strongly disagree $=1$," "I disagree=2," "I don't know=3," "I agree=4," "I strongly agree $=5 "(\mathrm{Al}, 2007)$.

The scale consists of three dimensions. They are emotional commitment, continuation commitment, and normative commitment. The initial six questions of the scale measures the emotional dimension of organizational commitment ( 1 , $2,3,4,5,6)$; subsequent six questions measure the continuation dimension $(7,8,9,10,11,12)$, and last six questions measure the normative dimension $(13,14,15,16,17,18)$ (Al 2007). The articles $3,4,5$, and 13 of the scale are scored reversely (Al, 2007; Oruç, 2013).

Meyer et al., (1993) have found the $0.82,0.74$, and 0.83 alpha values respectively for emotional, continuation, and normative commitment dimensions of organizational commitment. In our country, validity and reliability studies for organizational commitment scale have been conducted by many researchers and it was concluded that the scale does not differentiate from the original one in terms of the dimensions it contains (Al, 2007; Oruç, 2013; Mamedov, 2013).

\subsection{Data Analysis}

The distributions regarding the academicians' organizational justice perceptions and organizational commitment levels have been determined by means of calculating the arithmetic means and standard deviations of the responses given to the scales. The fact that whether the sub-dimensions of the organizational justice and organizational commitment scales are distributed normally or not has been experimented with the Kolmogorov-Smirnov test and Shapiro-Wilk test. It was observed through the tests that the data were not distributed normally and Spearman Brown Rank Correlation $(r)$ coefficient technique was used to determine the relation between the organizational justice perceptions and organizational commitment levels of academicians. In the construal of the correlation coefficient, if the result found is between 0.70 and 1.00, it was considered a relation level of high; of moderate when between 0.70 and 0.30 ; and of low when between 0.30 and 0.00 (Büyüköztürk, 2007).

The data obtained were analyzed on SPSS (Statistical Package for Social Scientists for Windows Release 18.0), their significance was checked at the level of 0.05 , other significance level was also specified, and the results were presented in the form of tables in keeping with the objective of the study.

\section{Findings}

It was determined that $78,2 \%(\mathrm{n}=410)$ of the academicians taking part in the research were male and $21,8 \%(\mathrm{n}=114)$ female; 
In the distribution as per ages, $24,2 \%(n=127)$ were at the age group of $36-40$ years; $21,4 \%(n=112), 41-45$ years; $19,8 \%$ $(n=104), 31-35$ years; $12,2 \%(n=64), 26-30$ years; $10,9 \%(n=57), 46-50$ years; $9,4 \%(n=49), 51$ years and above; and $2,1 \%(\mathrm{n}=11), 25$ years and below;

In the distribution as per the variable of the department where they work, 43,7\% ( $\mathrm{n}=229)$ were assigned at the teacher training school of physical education and sports; $25,8 \%,(n=135)$ at the coaching education department; 22,5\% $(n=118)$, at the sports management department; and $8 \%(n=42)$, at the recreation department;

In the distribution as per academic titles, 32,8\% $(\mathrm{n}=172)$ were assistant professor; $19,8 \%(\mathrm{n}=104)$, lecturer; $18,9 \%(\mathrm{n}=99)$, researcher; $15,6 \%(\mathrm{n}=82)$, instructor; $11,8 \%,(\mathrm{n}=62)$ associate professor; and $1,1 \%(\mathrm{n}=5)$, professor;

In their distribution as per professional seniority variable, $27,5 \%(n=144)$ were in service for $1-5$ years, $18,7 \%(n=98)$ for $16-20$ years, $16,6 \%(n=87)$ for $6-10$ years, $16,6 \%(n=87)$ for $11-15$ years, $11,5 \%(n=60)$ for $21-25$ years, and $9,1 \%(n=48)$ for 26 years and above;

In the distribution as per the variable of the marital status, 76,5\% ( $\mathrm{n}=401)$ were married; $19,3 \%(\mathrm{n}=101)$, single; and 4,2\% $(\mathrm{n}=22)$, separated/divorced/widowed;

In view of their scrutiny regarding whether they had an administrative assignment or not, $67,2 \%$ ( $\mathrm{n}=352$ ) of them did not have an administrative assignment (dean, vice dean, director of a school of higher education vice director, department head, section head, vice section head)and 32,8\% (n=172) were charged with such duties.

Table 2. The n, $\bar{X}$ and SS Values regarding the Academicians' Point Averages for the Organizational Justice Scale Sub-dimension.

\begin{tabular}{lccc}
\hline & $\mathbf{n}$ & $\overline{\mathbf{X}}$ & $\mathbf{S S}$ \\
\hline Distributive Justice & 524 & 3,32 & 0,86 \\
\hline Procedural Justice & 524 & 2,94 & 1,05 \\
\hline Transactional Justice & 524 & 3,28 & 1,04 \\
\hline
\end{tabular}

In the organizational justice scale of the school of physical education and sports academicians covered by the study, their point averages have been found as $\bar{X}=3,32$ for the distributive justice dimension; $\bar{X}=2,94$ for the procedural justice dimension; and $\bar{X}=3,28$ for the transactional justice dimension.

Table 3. The n, $\bar{X}$ and SS Values regarding the Academicians' Point Averages for the Organizational Commitment Scale Sub-dimension.

\begin{tabular}{lccc}
\hline & $\mathbf{n}$ & $\overline{\mathbf{X}}$ & SS \\
\hline Emotional Commitment & 524 & 3,54 & 0,91 \\
\hline Continuation Commitment & 524 & 3,29 & 0,72 \\
\hline Normative Commitment & 524 & 3,17 & 0,79
\end{tabular}

In the organizational commitment scale of the school of physical education and sports academicians covered by the study, their point averages have been found as $\bar{X}=3,54$ for the emotional commitment dimension; $\bar{X}=3,29$ for the continuation commitment dimension; and $\bar{X}=317$ for the normative commitment dimension.

Table 4. The Results of the Spearman Moments Multiplication Correlation Coefficient for the Determination of the Relation between the Academicians' Organizational Justice Scale Dimensions and Organizational Commitment Scale Dimensions

\begin{tabular}{lllccc}
\hline & & & \multicolumn{2}{c}{ Organizational Commitment Scale } \\
\cline { 3 - 6 } & & & $\begin{array}{c}\text { Emotional } \\
\text { Commitment }\end{array}$ & $\begin{array}{c}\text { Continuation } \\
\text { Commitment }\end{array}$ & $\begin{array}{c}\text { Normative } \\
\text { Commitment }\end{array}$ \\
\hline & Distributive & $\mathrm{r}$ & $0,343^{* *}$ & $0,155^{* *}$ & $0,368^{* *}$ \\
& Justice & $\mathrm{p}$ & 0,000 & 0,000 & 0,000 \\
\cline { 2 - 6 } & Procedural & $\mathrm{r}$ & $0,476^{* *}$ & $0,181^{* * *}$ & $0,453^{* *}$ \\
& Justice & $\mathrm{p}$ & 0,000 & 0,000 & 0,000 \\
\cline { 2 - 6 } & Transactional & $\mathrm{r}$ & $0,508^{* *}$ & $0,187^{* *}$ & $0,469^{* * *}$ \\
& Justice & $\mathrm{p}$ & 0,000 & 0,000 & 0,000 \\
\hline
\end{tabular}

\footnotetext{
${ }^{*}$ Significant at $\mathrm{P}<0.05$ level ${ }^{* *}$ Significant at $\mathrm{P}<0.01$ level
} 
In Table 4, the relation between the academicians' organizational justice scale and organizational commitment scale sub-dimensions has been scrutinized. It was determined upon such scrutiny that there is a relation between the organizational justice scale, distributive justice sub-dimension and organizational commitment scale, emotional commitment $(\mathrm{r}=0,343 ; \mathrm{P}<0,01)$ and normative commitment $(\mathrm{r}=0,368 ; \mathrm{P}<0,01)$ sub-dimensions at a moderate level and positive direction and between the continuation commitment $(\mathrm{r}=0,155 ; \mathrm{P}<0,01)$ sub-dimension at a low level and positive direction; between the organizational justice scale and procedural justice sub-dimension and organizational commitment scale, emotional commitment $(\mathrm{r}=0,476 ; \mathrm{P}<0,01)$ and normative commitment $(\mathrm{r}=0,453 ; \mathrm{P}<0,01)$ sub-dimensions at moderate level and positive direction and between the continuation commitment $(\mathrm{r}=0,181$; $\mathrm{P}<0,01$ )sub-dimension at low level and positive direction; between the organizational justice scale and transactional justice sub-dimension and organizational commitment scale, emotional commitment $(\mathrm{r}=0,508 ; \mathrm{P}<0,01)$ and normative commitment $(\mathrm{r}=0,469 ; \mathrm{P}<0,01)$ sub-dimensions at moderate level and positive direction and between the continuation commitment $(\mathrm{r}=0,187 ; \mathrm{P}<0,01)$ sub-dimension at low level and positive direction.

\section{Discussion and Conclusion}

Organizational justice includes the perceived justice of all the mutual change taking place in an organization socially or economically and the relation of individuals with their superiors, workmates, and the organization as a social system (Y1lmaz, 2004). School organization is a social open system (Yıldı, 2013) and this concept gains more importance in consideration of its close surroundings.

The distributive justice dimension of organizational justice is in relation with the fairness of the administrative decisions regarding the distributions of the gains of employees like remuneration or promotion (Karademir and Çoban, 2010).

The procedural justice dimension of organizational justice is in relation with the perceived justice of the methods, tools, and processes utilized in the distribution of gains (Yazıcıoğlu and Topaloğlu, 2009). In other words, it means the fairness of the rules in a workplace (Greenberg, 1990).

The transactional justice dimension of organizational justice is the perception of justice in relation with the manner of telling the decisions taken to the employees and of behaving in the social relations within the organization (Bedük, 2011).

It was determined that the highest perceptions of the school of physical education and sports academicians taking part in the study regarding justice was at the distributive justice $(\bar{X}=3,32)$ dimension; that it was followed by the transactional justice $(\bar{X}=3,28)$ and procedural justice $(\bar{X}=2,94)$ dimensions; and that the distributive, transactional, and procedural justice perceptions, whose characteristics are provided above, of academicians toward their institution was at "moderate" level in general; that is to say, they were not content with the decisions taken in that justice dimensions (distributive, transactional, procedural) (Table 2).

In consideration of the fact that the perception of employees regarding whether the administration within the organization is fair or not plays a significant part in their behaviors and attitudes toward that organization to a large extent (Y1lmaz, 2010), it is possible to assert that the academicians' perceptions must be higher because low organizational justice perception causes discontentedness in employees, affects their working performance (Cropanzano and Wright, 2003), and has the potential to alter the effort levels of them, to cause them exhibit negative behaviors, and to reduce their motivation by declining their job satisfaction (Y1lmaz, 2010).

In the studies that support our research results and that are oriented to teachers, other stakeholders of the education sector, (Tan, 2006; İmamoğlu, 2011; Ay, 2013; Günce, 2013; Y1ldız, 2013; Akgeyik, 2014), as well as in the study conducted on the employees of the Youth Services and Sports Provincial Directorate (Kurudirek, 2014), similar results were obtained.

In the respective literature, the studies that do not tally with the results of our study; that is to say, in the studies that conclude that teachers' organizational justice perception levels are high (Kazanc1, 2010; Acar, 2011; Çelik, 2011; Dündar, 2011; Babaoğlan and Ertürk, 2013; Akgüney, 2014; Gök, 2014; Kılıç and Demirtaş, 2014); are also present. It is possible to say that the teachers participating from different levels in such studies are content with the decisions taken in terms of the distribution of the gains like remuneration and promotion; of the perceived fairness of the methods, tools, and processes used in the distribution of the gains; and of the manner of telling the decisions taken to the employees and the way of behaving in the social relations within the organization.

Organizational commitment is a behavioral indicator of employees' attitudes and intentions toward the work and organization (Çakınberk and Aksel, 2009). In a larger expression, organizational commitment is in relation with the power of the attachment felt by employees toward their organization and means, concisely, the employees' loyalty to their organizations and interest in its potential of success (Bağc1, 2013).

The emotional commitment dimension of organizational commitment is the attachment of an employee to the 
organization in emotional grounds and with a sense of belonging and his/her identification of himself/herself with the organization. The employees having strong emotional commitment keep working within the organization at all times (Gülle, 2013).

The continuation commitment dimension of organizational commitment means the awareness of the costs brought along by the detachment from the organization. The continuation commitment is the state of continuing the membership of the organization considering that leaving it will be subject to high costs. Such commitment as a form of commitment forming through the idea that the gains of an employee, which he/she has acquired through labor, time, and efforts, such as status and money, during his/her employment at it will be lost upon leaving the organization (Kaya, 2012).

The normative commitment dimension of organizational commitment is that an individual who has commitment toward the organization normatively feels that he/she has a moral obligation toward staying with the organization. Normative commitment is closely related with self-devotion to the institution and loyalty. Normative commitment also covers the beliefs that are in relation with the organizational mission, goals, policies, and manners of operation and that are internalized by the individuals (İmamoğlu, 2011). Normative commitment is different from emotional commitment as the individual considers working for the organization a duty for him/her and thinks that his/her commitment toward the organization is the right thing and from the continuation commitment as he/she is not affected by the losses that will appear upon leaving the organization. The obligation in normative commitment does not depend on interests as in the continuation commitment but on wisdom and moral senses (Dolu, 2011).

It was determined that the highest performance of the school of physical education and sports academicians participating in the study in terms of commitment was at the emotional commitment $(\bar{X}=3,54)$ dimension; that it was followed by continuation commitment $(\bar{X}=3,29)$ and normative commitment $(\bar{X}=3,17)$ dimensions; and that, in general, the academicians' emotional commitments, whose characteristics are specified above, regarding their institutions, are high and their continuation and normative commitments are at a "moderate" levels (Table 3).

According to these results, we can say that academicians attach to their institutions in emotional ground and with a sense of belonging; that they identify themselves with the institution and they will continue working within the organization at all times; and that the fear of termination of the gains like status and money acquired through their labor, time, and effort upon the detachment from the organization does not constitute a high level among the reasons of their continuation with their institutions but their feeling of carrying a moral burden in relation with staying in the organization is not at a high level as well; that is to say, they do not bear the sense of complete devotion and loyalty toward their institution.

It is expected that the academicians with high level of emotional commitment toward their institutions will identify themselves with those institutions more; as a result of it, feel the objectives of the institution as if they were their own objectives; and endeavor to a large extent to solve the problems they encounter within the institution by exhibiting a performance that will increase the success of that institution (Y1ld1z, 2013). In addition, within the literature regarding organizational commitment, the most wanted situation for the level of importance, one of the dimensions of organizational commitment, in employees, is the presence of high emotional commitment (Brown, 2003).In consideration of such issues, it is possible to say that the result obtained from the study is pleasing.

In the respective literature, there are numerous studies supporting the results of the study partially or completely. It was determined in those studies; by Çakır (2007) that the emotional, continuation-based, and normative commitments of primary school teachers is at moderate level; by Boylu et al., (2007) that the emotional commitments of academicians is high and their continuation-based and normative commitments are at moderate levels; by Başyiğit (2009) that the emotional commitments of primary school teachers are high and their continuation-based and normative commitments are at moderate levels; by Kiray (2011) that the emotional commitments of academicians are high and their continuation-based and normative commitments are at moderate levels; by Kurtbaş (2011) that the emotional, continuation-based, and normative commitments of academicians are at moderate levels; by Canpolat (2011) that the emotional commitments of primary school teachers are high and their continuation-based and normative commitments are at moderate levels; by Akyol et al (2013) that the emotional, normative, and continuation-based commitments of the physical training and classroom teachers are at moderate levels; by Özgan et al., (2012) that the emotional, normative, and continuation-based commitments of lecturers are at moderate levels; by Y1ldiz (2013) that the emotional and normative commitments of primary school teachers are at high levels and their continuation-based commitments are at moderate levels; by Ertürk (2014) that the emotional commitments of secondary school teachers are high and their continuation-based and normative commitments are at moderate levels; by Dalkiran (2014) that the emotional commitments of the academicians of physical training and sports schools of higher education are high and their continuation-based and normative commitments are at moderate levels.

Upon the scrutiny of the relation between the organizational justice dimensions and the organizational commitment 
dimensions of the academicians of the school of physical education and sports, following results have been obtained (Table 4):

It was determined that a moderate-level and positive directional relation is present between the distributive justice dimension of organizational justice and emotional commitment and normative commitment dimensions of organizational commitment and there is low-level positive-directional relation with its continuation commitment dimension.

According to the result, it can be said that the high perception of academicians regarding the fairness of the administrative decisions in relation with the distribution of the gains like remuneration and promotion in their institutions will increase their commitments toward their attachment to their institutions emotionally and with a sense of belonging; identification with their institution and feeling that their continuation with the institution are a moral obligation; considering their work for the institution is a duty for them; and thinking that their commitment to the institution is a true behavior.

It was determined that a moderate-level and positive directional relation is present between the procedural justice dimension of organizational justice and emotional commitment and normative commitment dimensions of organizational commitment and there is low-level positive-directional relation with its continuation commitment dimension.

According to the result, it can be said that the high perception of academicians regarding the fairness of the methods, tools, and processes used in the distribution of the gains in their institutions and of the rules at their workplace will increase their commitments toward their attachment to their institutions emotionally and with a sense of belonging; identification with their institution and feeling that their continuation with the institution is a moral obligation; considering their work for the institution is a duty for them; and thinking that their commitment to the institution is a true behavior.

It was determined that a moderate-level and positive directional relation is present between the transactional justice dimension of organizational justice and emotional commitment and normative commitment dimensions of organizational commitment and there is low-level positive-directional relation with its continuation commitment dimension.

According to the result, it can be said that the positive justice perception of academicians regarding the manner of telling the decisions taken to the employees and the way of behaving in the social relations within the organization will increase their commitments toward their attachment to their institutions emotionally and with a sense of belonging; identification with their institution and feeling that their continuation with the institution is a moral obligation; considering their work for the institution is a duty for them; and thinking that their commitment to the institution is a true behavior.

In the studies performed within the literature, exhibiting parallelism with the results of our study, and oriented to academicians (Kıray, 2011), teachers (İmamoğlu, 2011; Ay, 2013; Selvitopu and Şahin, 2013; Bal, 2014; Günce, 2013; Gök, 2014) and varied researchgroups (Yazıcıoğlu and Topaloğlu, 2009; Eğilmezkol, 2011; Işık et al., 2012; Arslantürk and Şahan, 2012; Bağcı, 2013; İçöz, 2014; Yanılmaz, 2014), it was determined that there is a positive and significant relation between organizational justice and organizational commitment; that is to say, the organizational commitment of individuals will increase in parallel with the increase of their perception of organizational justice.

\section{References}

Acar, G. (2011). The relationship between the ethical leadership behaviors by school managers and the organizational justice and motivation levels of physical education teachers. Ph.D Thesis, Gazi University Institute of Education Sciences, Ankara, Turkey.

Akgeyik, G. (2014). The perceptions of organizational justice of administrators and teachers in Anatolian high schools (Diyarbakır province example). Master's Degree, Dicle University Institute of Education Sciences, Diyarbakır, Turkey.

Akgüney, E. (2014). The relationship between teachers' perceptions of organizational justice and organizational citizenship behaviours. Master's Degree, Marmara University Institute of Education Sciences, İstanbul Turkey.

Akyol, P., Atan, T., \& Gökmen, B. (2013).An examination of the organizational commitment levels of physical education and primary school teachers. Journal of Sports and Performance Researches, 4(1), 38-45.

$\mathrm{Al}$, A. (2007). Investigating the managerial competency level of the principals at foreign languages departments of the universities and the level of commitment to the organization of the instructors of English. Master's Degree, Kocaeli University Institute of Social Sciences, Kocaeli, Turkey. 
Arslantürk, G., \& Şahan, S. (2012). Analyzing of the relationship between organizational justice and organizational commitment in Manisa police department. Turkish Journal of Police Studies, 14, 135-159.

Atalay, D. D. (2007). The relationship between perceived organizational justice and organizational commitment in terms of equity sensitivity. Ph.D Thesis, Ankara University Institute of Social Sciences, Ankara, Turkey.

Ay, F. A., Ulusoy, H., \&Tosun, N. (2015). Determination of organizational commitment level of academicians who are working at a state university. The Journal of International Social Research, 8(36), 749-762.

Ay, G. (2013). A comparative analysis to determine the relation between the perception of organizational justice and level of organizational commitment of teachers'. Master's Degree, Gazi University Institute of Education Sciences, Ankara, Turkey.

Babaoğlan, E., \& Ertürk, E. (2013). The relationship between teachers' organizational justice perception and organizational commitment. H.U. Journal of Education, 28(2), 87-101.

Bağc1, Z. (2013). The impacts of justice perceptions of employees on organizational commitments: An investigation in textile sector. International Journal of Management Economics and Business, 9(19), 164-168.

Bal, V. (2014). Organizational justice and organizational commitment relationship: A study in educational institutions in Manisa. Journal of ASU FEAS, 6(1), 1-9.

Başyiğit, F. (2009). The relationship between the level of teachers? Participation to decision-making process and the level of organizational commitment. Master's Degree, Gazi University Institute of Education Sciences, Ankara, Turkey.

Bedük, A. (2011). Recent advances in organizational psychology. Konya, Dizgi Atlas Akademi.

Belli, E., \& Ekici, S. (2012). A research on organizational commitment of personal working at provincial directorates of youth and sports in aegean region. Selcuk University Journal of Physical Education and Sport Science, 14(2), 171-178.

Boylu, Y., Pelit, E., \& Güçer, E. (2007). A study on the level organisational commitment of academicians.Journal of Finance Politic \& Economic Comments, 44(511), 55-74.

Bozkurt, Ö., \&Yurt, İ. (2013). A study to determine the organizational commitment level of the academicians. Journal of Administrative Sciences, 11(22), 121-139.

Brown, B. B. (2003). Employees' organizational commitment and their perception of supervisors' relations-oriented and task-oriented leadership behaviors. Phd Thesis, Falls Church, Virginia.

Büyüköztürk, Ş. (2007). Manual data analysis for the social sciences. Seventh Edition. Ankara, Pegem A Publications.

Büyüköztürk, Ş., Çakmak, E. K., Akgün, Ö. E., Karadeniz, Ş., \& Demirel, F. (2014). Scientific research methods. 18. Edition. Ankara, Pegem A Publications.

Çakınberk, A., \& Aksel, İ. (2009). The empirical research of organizational commitment on midwifes and nurses in health centers in Malatya. e -Journal of New World Sciences Academy, 4(3), 277-298.

Çakır, A. (2007). An analysis of the relation between the primary school teachers organisational commitment levels and perceptions of school culture. Master's Degree, Yeditepe UniversityInstitute of Social Sciences, İstanbul, Turkey.

Canpolat, C. (2011). The relationships between teacher career ladders implementation and teacher motivation and organisational commitment. Master's Degree, Firat University Institute of Education Sciences, Elazığ, Turkey.

Çelik, O. T. (2011). The relationship between primary school manager's and teacher's perception of organizational justice and job satisfaction. Master's Degree, Selçuk University Institute of Education Sciences, Konya, Turkey.

Çilenti, M. (1984). Education technology and teaching. Ankara, Kadığlu Publications.

Cropanzano, R., \& Wright, T. A. (2003). Procedural justice and organizational staffing: A tale of two paradigms. Human Resource Management Review, 13, 7-39.https://doi.org/10.1016/S1053-4822(02)00097-9

Dalkıran, E. (2014). The relation between organizational commitment and managerial effectiveness in instructors at school of physical education and sports. Master's Degree, Selçuk UniversityInstitute of Health Sciences, Konya, Turkey.

Dolu, B. (2011). A survey on the organizational commitment levels of employees in the banking sector. Graduation Project without Thesis, Süleyman Demirel University Institute of Social Sciences, Isparta, Turkey.

Dündar, T. (2011). The relationship between organizatonal justice perceptions and job satisfaction levels. Master's Degree, Yıldız Teknik University Institute of Social Sciences, İstanbul, Turkey. 
Eğilmezkol, G. (2011). Organizational justice and organizational commitment in work life, a study aimed at the analysis of the organizational justice and organizational commitment of the employees in a public bank. Master's Degree, Gazi University Institute of Social Sciences, Ankara, Turkey.

Erkanl1, H. (2009). The relationship between organizational justice and culture: A comparative study in some organizations in Turkey. Ph.D Thesis, Ankara University Institute of Social Sciences, Ankara, Turkey.

Ertürk, R. (2014). The relationship between work motivation of teachers and their organizational commitment: The sample of Bolu. Master's Degree, Abant İzzet Baysal University Institute of Education Sciences, Bolu,Turkey.

Gök, D. (2014). A study of primary school and secondary school teachers' perceptions of organisational justice and organisational commitment in terms of some parameters: Şahinbey/Gaziantep example. Master's Degree, Gaziantep University Institute of Education Sciences, Gaziantep, Turkey.

Greenberg, J. (1990). Looking fair vs. being fair: Managing impressions of organizational justice. Research in Organizational Behavior, 12, 111-157.

Gülle, M. (2013). Investigation of physical education and sport teachers exposure mobbing and organizational commitment status in school environment: Hatay sample. Master's Degree, Sakarya University Institute of Education Sciences, Sakarya, Turkey.

Günce, S. (2013). Relationship between organizational justice and organizational commitment in primary schools.Master's Degree, Harran UniversityInstitute of Social Sciences, Şanlıurfa, Turkey.

Günsal, E. (2010). The relationship between perceived organizational justice and organizational alienation and a research. Master's Degree, Marmara UniversityInstitute of Social Sciences, İstanbul, Turkey.

İçöz, D. (2014). The effects of the perceived organizational justice on the organizational commitment: The case of manufacturing industry in Kayseri. Master's Degree, Nevşehir Hacı Bektaş Veli UniversityInstitute of Social Sciences, Nevşehir, Turkey.

İmamoğlu, G. (2011). The relationship between primary school teachers? Organizational commitment levels and organizational justice. Master's Degree, Gazi University Institute of Education Sciences, Ankara, Turkey.

Işık, O., Uğurluoğlu, Ö., \& Akbolat, M. (2012). The effect of organizational justice perceptions on organizational commitment in the healthcare sector. Doğuş University Journal, 13(2), 254-265.

Karademir, T., \& Çoban, B. (2010). View of the organizational justice theory in sport management constitution. Nigde University Journal of Physical Education and Sport Sciences, 4(1), 48-62.

Kaya, İ. (2012). The effect of the factors affecting the quality of work life in hotel enterprises on the organizational commitment: The case of Marmaris. Master's Degree, Balıkesir UniversityInstitute of Social Sciences, Balıkesir, Turkey.

Kazanc1, N. (2010).The styles of leaderships of primary school administers and the relationships between the teachers? organizational justice perception. Master's Degree, Sakarya UniversityInstitute of Social Sciences, Sakarya, Turkey.

Kılıç, Y., \& Demirtaş, Z. (2014). The perceptions of organizational justice of secondary teachers. Journal of Research in Education and Teaching, 4(2), 46-58.

Kıray, A. (2011). An empirical study towards identifying the relationship between organizational justice and organizational commitment. Master's Degree, Çanakkale Onsekiz Mart UniversityInstitute of Social Sciences, Çanakkale, Turkey.

Kurtbaş, D. (2011). Organizational commitment to the relationship between psychological violence scholars are exposed to public and the research foundation universities. Master's Degree, Gazi University Institute of Education Sciences, Ankara, Turkey.

Kurudirek, M. A. (2014). Relationship between organizational justice and job satisfaction: A study on personnel of the Eastern Anatolia Region Provincial Directorate of Youth Welfare and Sports. Ph.D Thesis, Atatürk UniversityInstitute of Health Sciences, Erzurum, Turkey.

Mamedov, B. (2013). Job satisfaction and organizational commitment. Master's Degree, İstanbul UniversityInstitute of Social Sciences, İstanbul, Turkey.

Meyer, J. P., Allen, N. J., \& Smith, C. A. (1993). Commitment to organizations and occupations: Extension and test of a three-component conceptualization. Journal of Applied Psychology, 78(4),

538-551. https://doi.org/10.1037/0021-9010.78.4.538 
Niehoff, B. P., \& Moorman, R. H. (1993). Justice as a mediator of the relationship between methods of monitoring organizational citizenship behavior. Academy of Management Journal, 36(3), 527-556. https://doi.org/10.2307/256591

Oruç, M. (2013). The relationship between organizational commitment and organizational silence: A research in a firm. Master's Degree, Marmara UniversityInstitute of Social Sciences, İstanbul, Turkey.

ÖSYS. (2014). The student selection and placement system, higher education programs and quotas guide, http://dokuman.osym.gov.tr/pdfdokuman/2014/OSYS/Tercih/2014-OSYSKONTKILAVUZU01072014.pdf, [01/05/2014]

Özgan, H., Külekçi, E., \& Özkan, M. (2012). Analyzing of the relationships between organizational cynicism and organizational commitment of teaching staff. International Online Journal of Educational Sciences, 4(1), 196-205.

Selvitopu, A., \& Şahin, H. (2013). The relationship between organizational justice perceptions and organizational commitment levels of secondary school teachers. Journal of Kırşehir Education Faculty (JKEF), 14(2), 171-189.

Tan, Ç. (2006). The primary school teachers' perceptions about organizational justice. Master's Degree, Firat UniversityInstitute of Social Sciences, Elazığ, Turkey.

Yanılmaz, B. (2014). Investigation of the relationship between organizational justice perception and organizational commitment level of civil servants. Master's Degree, Maltepe UniversityInstitute of Social Sciences, İstanbul, Turkey.

Yazıcı̆ğlu, İ., \& Topaloğlu, I. G. (2009). The relationship between organizational justice and commitment: A case study in accommodation establishments. Journal of Business Research-Turk, 1(1), 3-16.

Yıldırım, F. (2002). Relationship in organizational commitment and organizational justice within working life. Ph.D Thesis, Ankara University Institute of Social Sciences, Ankara, Turkey.

Yıldız, K. (2013). Teachers' organizational justice and organizational trust perceptions. AIBBU Journal of Social Sciences, 13(1), 289-316.

Yllmaz, G. (2004). The effect of organizational justice perception regarding human resource practices on employees attitudes and behaviors. Ph.D Thesis, İstanbul UniversityInstitute of Social Sciences, İstanbul, Turkey.

Yilmaz, K. (2010). Secondary public school teachers' perceptions about organizational justice. Educational Science: Theory \& Practice, 10(1), 579-616.

\section{Copyrights}

Copyright for this article is retained by the author(s), with first publication rights granted to the journal.

This is an open-access article distributed under the terms and conditions of the Creative Commons Attribution license which permits unrestricted use, distribution, and reproduction in any medium, provided the original work is properly cited. 